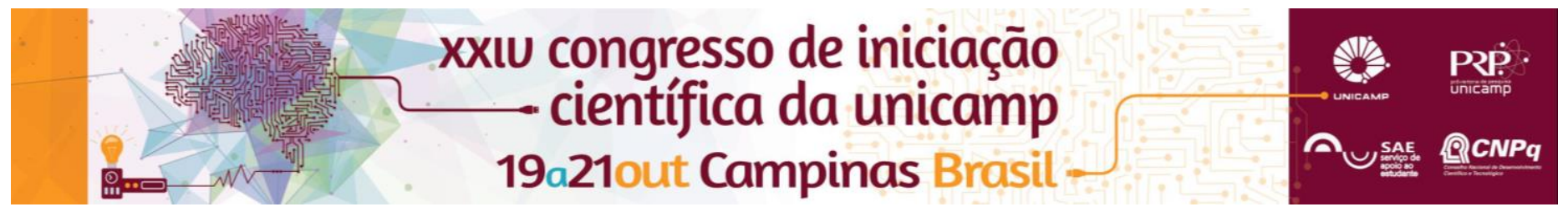

\title{
MODIFICAÇÃO DA CONSISTÊNCIA E MICROESTRUTURA DE ÓLEO DE PALMA ATRAVÉS DA INTERESTERIFICAÇÃO ENZIMÁTICA COM ÓLEO DE CANOLA E FITOESTERÓIS LIVRES.
}

\author{
Monise Helen Masuchi Buscato, Barbara Gallani Zaia*.
}

\section{Resumo}

O projeto em questão visa o desenvolvimento de gorduras com redução de ácidos graxos saturados através da interesterificação enzimática, juntamente com a adição de fitoesteróis livres como estruturantes da rede cristalina. Os experimentos foram feitos com bases lipídicas tendo concentrações complementares de $0 \%$ a $100 \%$ de óleo de canola com óleo de palma, as quais foram interesterificadas e qualificadas quanto características físico-químicas das amostras. Foi possível observar a estruturação das matérias lipídicas ao ser adicionado o fitoesterol livre, porém em alguns casos com a mistura interesterificada houve diminuição da consistência pela alta concentração de diacilgliceróis encontrados.

\section{Palavras-chave}

Bases lipídicas, redução de saturados, interesterificação e fitoesteróis livres.

\section{Introdução}

Óleos e gorduras são matérias-primas constituídas principalmente de glicerídeos de ácidos graxos, sendo os ácidos graxos saturados aqueles que possuem maior ponto de fusão que quando ingeridos, esses podem acarretar problemas à saúde. Com a mistura de bases lipídicas, interesterificação enzimática e a adição de estruturante, no caso fitoesterol livre, podem ser obtidas gorduras com estrutura mais coesa e mais firme possibilitando a diminuição de ácidos graxos saturados.

\section{Resultados e Discussão}

Foram feitas misturas de duas bases lipídicas, tendo concentrações complementares de $0 \%$ a $100 \%$ de óleo de canola com óleo de palma. A partir da composição em ácidos graxos foi possível observar que o óleo de canola é uma matéria-prima com alto teor de ácido oleico $(61,4 \%$ - C18:1) diferentemente do óleo de palma que tem alta concentração de ácido oleico mas também alta concentração de ácido palmítico (40,5\% - C16:0) representando a fração com maior quantidade de ácidos graxos saturados nas misturas utilizadas.

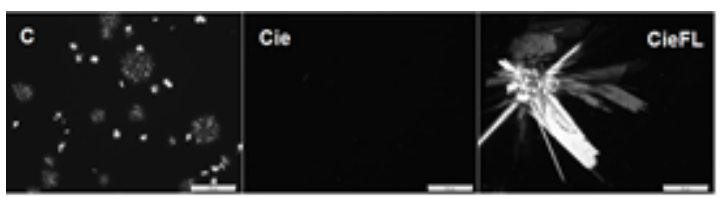

Figura 1. Imagens microscópicas da mistura $C$ antes e depois da interesterificação enzimática e depois da adição de fitoesteróis livres.

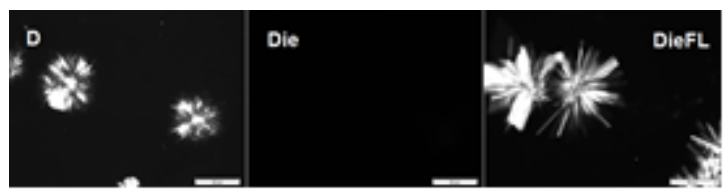

Figura 2. Imagens microscópicas da mistura $D$ antes e depois da interesterificação enzimática e depois da adição de fitoesteróis livres.
A adição de fitoesterol livre foi verificada através da microscopia sob luz polarizada, pela presença de estruturas fibrilares.

A ação da interesterificação enzimática foi observada a partir da análise de composição em triacilgliceróis ao qual como exemplo a mistura C (OP:OC - 60:40) e D (OP:OC - 40:60) antes da reação de interesterificação obteve respectivamente $24,58 \%$ de POP e $19,32 \%$ de OOO de triacilglicerol em maior percentual, depois da interesterificação esse triacilglicerol foi alterado, sendo da mistura C e D: $23,76 \%$ de $\mathrm{POO}$ e $22,94 \%$ de $\mathrm{POO}$ também.

A reação de interesterificação é um processo importante pela capacidade de modificação de bases lipídicas. Neste trabalho, a reação de interesterificação gerou a formação de diacilgliceróis, dificultando a cristalização e estruturação desejada das misturas feitas.

\section{Conclusões}

Foi possível obter modificações nas misturas preparadas, sendo elas favoráveis em alguns casos na presença do fitoesterol mostrando o poder estruturante desse aditivo e desfavoráveis em alguns casos principalmente relacionados a formação de diacilgliceróis provindos da interesterificação enzimática.

\section{Agradecimentos}

Agradeço a minha orientadora, aos fornecedores de matéria-prima (AgroPalma e M.Cassab) e ao laboratório de Óleos e Gorduras (FEA) e Laboratório de Engenharia de Produtos e Processos em Biorrecursos (FEQ).

\footnotetext{
${ }^{1}$ MARANGONI, A. G., ROUSSEAU, D. Engineering triacylglicerols: the role of interesterification. Trends in Food Science and Technology, v. 6, p. 329-336, Oct. 1995.

- GUNSTONE, F.D. Vegetable Oils. In: Bailey's Industrial Oil \& Fats Products. 6.ed. Wiley-Interscience, v.1 p.248-250, 2005.
} 